\title{
A Crise da Pesquisa em Saúde
}

\author{
Prof. Paulo Marchiori Buss*
}

O setor de ciência e tecnologia nacional vive hoje uma crise de dimensões profundas e inusitadas. Mergulhadas no contexto geral da crise financeira do Estado urasileiro, vêm as instituiçōes de pesquisa nacionais sofrendo severas restriçóes de recursos que ameaçam paralisar ou atrasar irremediavelmente a produção científica em nosso país.

Quais são os principais componentes da crise mencionada? Em primeiro lugar, a contração dos recursos aplicados pelos Governos Federal e Estaduais no campo da ciência e tecnologia. De fato, em termos reais os recursos vêm caindo na década de 80 , com acentuação deste quadro no ano de 1988. As perdas inflacionárias do período jamais foram repostas e a dura realidade é que por todo este segundo semestre do ano cessou o fluxo até dos recursos já comprometidos. Isto levou as instituiçōes a atitudes táo nocivas como suspender projetos de investigaçáo que estavam em andamento; adiar estudos e pesquisas prioritárias que estavam por começar; dispensar (o que significa, às vezes, perder irremediavelmente) recursos humanos jovens e talentosos, por absoluta falta de recursos para pagá-los; e desmoronar os indispensáveis laços de confiança entre a comunidade acadêmica e o Estado como um todo.

Um outro elemento central da crise é o desgovemo no setor de ciência e tecnologia do país. De fato, para exemplificar, podemos mencionar a atitude do Mínistro da Ciência e Tecnologia no episódio da "reorganização" do Conselho Deliberativo do CNPq, esvaziando-o por completo da representação acadêmica. Finalmente, por mobilização da comunidade científica, de que esta Escola participou ativamente, o processo foi revertido, levando-se para um "reexame" o texto assinado à noite, pelo Ministro e pelo Presidente, no apagar das luzes do poder legal do decretolei. De outro lado, as injustificadas demissōes na FlNEP, alterando uma composição técnica que já começava a produzir seus melhores frutos tendem a aprofundar o fosso que separa a comunidade científica das agências de fomento e do Governo.

O Ministério da Saúde, por seu lado, nāo garante a continuação do seu Programa de Estudos e Pesquisas em Políticas de Saúde (PESPS), com o encerramento do apoio financeiro intemacional. Lamentável, quando se sabe do significativo número de projetos apoiados

-Vice-Diretor da ENSP, Secretario-Executivo da $A B R A S C O$ 
e da qualidade dos produtos, avaliados que foram em Seminário desenvolvido neste ano, em Brasília.

É importante examinar também o que aconteceu com as restriçōes legais à incorporação de pessoal pelo Governo Federal durante todo este ano. Em inúmeras instituições públicas os recursos porventura existentes, mesmo os de agências internacionais, ficaram parados pela impossibilidade de se incorporar os profissionais previstos, ainda que em contratos de tempo determinado, condicionado ao período de realização da pesquisa e de existência dos recursos externos.

Os prejuízos para o desenvolvimento técnicocientífico nacional, com toda esta gama de empecilhos, são suficientemente evidentes. Entretanto, quando se examina a questão da Saúde, os prejuízos e a nocividade das medidas tomadas (ou, justamente as naao tomadas) ressaltam-se ain da mais. De fato, as questões colocadas hoje para a sociedade brasileira no campo da saúde são de tal monta e complexidade que mereceriam uma particular atenção por parte dos Governos de qualquer dos níveis de poder. Para mencionar apenas algumas, podemos referir o escasso conhecimento do quadro nosológico e de mortalidade no país, com algum grau de particularidade, que permitisse o estabelecimento dos perfis epidemiológicos e, por decorrência, o direcionamento de programas de atividade por parte dos órgãos sanitários. Num outro plano, propositalmente distinto deste, bastaria que citássemos a questão da avaliação de tecnologias no campo da saúde, num momento em que o mundo (e o Brasil) vivem agudamente o incremento de custos da assistência médica. Enfim, tantos e tantos outros exemplos poderiam citar, que mostram o prejuízo decorrente do decréscimo dos recursos e do desgoverno no setor de ciência e tecnologia para o desenvolvimento do sistema de saúde em nosso país, mas năo queremos cansar o leitor com a extensão do diagnóstico.

$\mathrm{Na}$ verdade, o que se impóe para todos nós neste momento $E$ esclarecer o Congresso Nacional sobre a questáo, na oportunidade em que vota o orçamento federal de 1989. Um dos caminhos para a redenção do país está no investimento sério, contínuo e de largo prazo que se fizer no Setor de Ciência e Tecnologia nacional, com vistas a produzir conhecimento adequado e formar recursos humanos de alto nível. É evidente que ninguém ignora a crise econômica que atravessa o país e a conseqüente escassez geral de recursos. Mas acreditamos firmemente na necessidade de poupar da destruição as instituiçōes nacionais de pesquisa. Quando menos, pelo redirecionamenteo da aplicação dos recursos públicos em obras de eficácia duvidosa e, quando corajosa e patrioticamente, gerando os excedentes para aplicação no país pela negação e o não-pa- 
gamento da imoral dívida extema de que tentam nos convencer da legalidade.

Entretanto, seria medíocre nos restringirmos a uma proposta que deve parecer óbvia a todos quando se trata de financiamento regular e estável das linhas de investigação em Saúde Coletiva no país: o aumento, ou, pelo menos, a manutenção dos recursos orçamentários das agências públicas de fomento à pesquisa dos poderes federal, estadual e municipal.

Penso que devemos caminhar, ainda, para a adoção de poderosos mecanismos alternativos:

a) a extensão da Lei Samey, dedicada à cultura, também à Ciência e Tecnologia, - neste caso vale a pena comentar a necessidade da adoção de um movimento agressivo de "marketing" da pesquisa por parte das entidades acadêmicas e científicas, inicialmente junto ao Congresso Nacional e, após a obtenção do benefício, também junto às empresas potencialmente financiadoras de investigações, mantidas evidentemente na plenitude de sua importância e prioridade, os limites éticos exigidos pela atividade científica;

b) o financiamento da investigação, via acordos de cooperaçāo técnica direta, năo intermediados por agências públicas de fomento à pesquisa, entre os serviços públicos (e privados) de saúde $e$ as Instituiçōes de pesquisa, acadêmicas ou não - é o caso de fomentar os acordos diretos, em tomo de questōes específicas e de interesse mútuo, entre as Secretarias de Saúde dos Estados e dos Municípios com as entidades de pesquisa, como fez o INAMPS com a ENSP, por exemplo, em anos recentes, em projetos de resultados extremamente animadores;

c) a constituição de um programa de pesquisas conjunto, ligando as entidades sindicais e associativas dos profissionais de saúde $e$ as entidades acadêmicas, nos moldes do que representam o DIEESE ou o DIESAT para o movimento sindical dos trabalhadores em geral - a definição conjunta das linhas de pesquisa podem garantir, com boa margem de segurança, a escolha adequada dos objetivos de estudo, ao mesmo tempo que se poderia garantir um fluxo estável de recursos oriundos diretamente dos profissionais da saúde e independente portanto da burocracia estatal

d) a adoção de taxas de administração (ou mecanismos equivalentes) por parte das entidades acadêmicas e científicas, em relação a todos seus projetos de investigação, com vistas ao financiamento da chamada "pesquisa difícil", "não vendável" 
com os mecanismos propostos, bem como para o financiamento de certos itens dificilmente financiáveis pelas agências de fomento;

e) a organização de associaçōes de pesquisadores de caráter civil-privado, capazes de superar os impasses criados pelas burocracias do poder central ou do poder local da própria instituição, com mecanismos de controle transparentes e, quiçá, definidos e ligados à própria instituição - só assim se poderiam superar os entraves (e os atrasos) absurdos que freqüentemente se interpöem entre os recursos existentes e a realização das investigações.

Enfim, devemos nos mobilizar para as lutas nos campos extra e intra-institucional, como forma de assegurar os recursos necessários para o desenvolvimento da pesquisa em saúde, fundamental para a melhoria da atenção à saúde do povo brasileiro. 